\title{
Treatment and reinforcement of the loose sands of the city of Kenitra
}

\author{
Hajar Boukhorb ${ }^{1, *}$, Lahcen Bahi ${ }^{1}$, Latifa Ouadif ${ }^{1}$, Houssine Ejjaaouani ${ }^{2}$, and Abdeloihad Gourri ${ }^{2}$ \\ 13GIE Laboratory, Mohammadia Engineering School, Mohammed V University Rabat, Morocco \\ ${ }^{2}$ LPEE Public Laboratory for tests and studies, Morocco
}

\begin{abstract}
The Kenitra city belongs to the Rharb-Mamora domain, which is affected by a continuous subsidence from the Middle Vindobonien to the present day. The sedimentary cycle of the tertiary era ends at the Pliocene, characterized by regressive character deposits identified in outcrop at the margins of the basin: They are conglomerates in the North, yellow sands in the East, sands and sandstone in the South-East. These sandy deposits vary from more or less clayey sand to greying sand, with the appearance of a very loose sand layer, at varying depths. It is with this directive that the objective of this article is to define the risks, which may affect the works built on this soil, and also determine the actions to be taken to control these risks. As a first step, an experimental approach was carried out, including in situ and laboratory tests in order to identify these formations and define their mechanical behavior. Then, the results of geotechnical survey were analyzed and exploited in calculations of bearing capacity, settlement, liquefaction,... eventually resulting in the necessity of treatment and reinforcement of this soil. These approaches have shown that there are several soil reinforcement techniques, the choice of which depends on the granulometry of soil and the cost of project.
\end{abstract}

\section{Introduction}

Liquefaction is one of the most important and complex phenomenon in the dynamics of loose soil. In highly seismic areas, this phenomenon is responsible for excessive damage to building foundations. Historically, the major repercussions occasioned in Japan in 1964 by the Nigata seism, have stimulated several research to apprehend the risk of liquefaction and evaluate its consequences according to a given seismic intensity (Seed, 1971; Robertson \& Wride, 1998; Boulanger \& Idriss, 2008; Moss et al., 2006). Thus, several empirical approaches based, in particular, on the results of in situ tests, have been developed in order to analyze the liquefaction potential of soil.

The Kenitra city is clearly invaded by sandy deposits varying from more or less clayey sand to grazed sand, with the appearance of a very loose layer of sand at varying depths. From which it is necessary to improve the characteristics of these sands by choosing the optimal solution and the most suitable for this type of soil.

To this end, a detailed study was carried out in the Kenitra city, including the evaluation of soil bearing capacity, the estimation of soil settlement, the verification of the risk of liquefaction and finally the choice of the most suitable treatment with its dimensioning and the evaluation of liquefaction mitigation by this treatment.

\section{Methodology}

After the completion of a geotechnical survey in the city of kenitra, we carried out calculations of the bearing capacity and settlement of soil, the evaluation of the liquefaction risk and finally the treatment and reinforcement of the soil.

\subsection{Calculation of bearing capacity and settlement generated}

The calculation of the bearing capacity was carried out according to Fascicule 62, title V [1].

The superficial foundation elements are based on results of pressuremeter tests. $\mathrm{P}$

The effort $\mathrm{F}$ applied to the foundation is assumed to be vertical and centered. The permissible stress was calculated by the following formula:

$$
\sigma_{a}=\frac{P l e * . K p}{F}+q o
$$

With:

$\mathrm{K}_{\mathrm{p}}$ : Pressuremeter bearing factor;

$\mathrm{P}_{\mathrm{le}}$ *: Equivalent net limit pressure;

$\mathrm{F}$ : Safety factor ( $\mathrm{F}=3$ for shallow foundations).

$\mathrm{q}_{\mathrm{o}}=0\left(\gamma^{*} \mathrm{~h}\right)$; since the weight of the land at the base of the foundation is considered negligible compared to the permissible load ofthe foundation, taking into account the depths involved.

\footnotetext{
*hajar.boukhorb@gmail.com
} 
According to TERZAGHI, the vertical deformation of a formation under a given service load, mobilizes three types of consecutive compression in time, which are active during and after the loading, either:

$>$ Primary consolidation;

$>$ Secondary consolidation;

$>$ The rheological dynamics.

The estimated final settlement, noted Sf, is such that:

$$
S_{f}=S_{c}+\mathrm{Sd}
$$

With:

$$
\begin{gathered}
S_{c}=\frac{\alpha}{9 E_{c}}\left(\sigma-\gamma_{D}\right) \cdot \lambda_{c} \cdot B \\
S_{d}=\frac{2}{9 E_{d}}\left(\sigma-\gamma_{D}\right) \cdot B_{0} \cdot\left(\lambda_{d} \cdot \frac{B}{B_{0}}\right) \alpha
\end{gathered}
$$

Where:

$\mathrm{B}_{\mathrm{o}}$ : Reference dimension $(0.6 \mathrm{~m})$;

B: Width of the foundation;

$\sigma$ : Vertical stress applied by the foundation;

$\gamma_{D}$ : Total vertical stress before works at the base of foundation ;

$E_{c}, E_{d}$ : Equivalent pressuremeter modulus of the soil ;

$\alpha$ : rheological factor function of the type of soil and its mechanical behavior;

$\lambda d$ and $\lambda c$ : Footing shape factors function of $L / B$, where $\mathrm{L}$ is the length of the foundation.

\subsection{Assessment of liquefaction risk}

In the presence of the groundwater, the liquefaction resistance is evaluated by applying the NCEER method, developed by Youd and Idriss, on the basis of the results of the Standard Penetration Test (SPT) [2-5].

The risk of soil liquefaction is given by the safety factor [2]:

$$
F . S=\frac{C R R}{C S R}
$$

With:

CSR: Cyclic Stress Ratio.

CRR: Cyclic Resistance Ratio.

According to the RPS 2000 version 2011 [6], liquefaction occurs if the ratio:

$$
\frac{C S R}{C R R}>0.75
$$

\subsubsection{Evaluation of CSR}

Seed and Idriss 1971 [2] formulated the following equation for calculation of the cyclic stress ration CSR:

$$
C S R=\left(\frac{\tau_{a v}}{{\sigma^{\prime}{ }_{v 0}}}\right)=0.65\left(\frac{a_{\max }}{g}\right)\left(\frac{\sigma_{v 0}}{\sigma_{v 0}^{\prime}}\right) r d
$$

Where $\tau_{\mathrm{av}}$ is the average cyclic shear stress; $\mathrm{a}_{\max }$ is the maximum horizontal acceleration at the ground surface; $g$ is the acceleration of gravity; $\sigma_{\mathrm{v} 0}$ is the vertical

khajar.boukhorb@gmail.com total stress; $\sigma^{\prime}{ }_{v 0}$ is the vertical effective stress; $r_{d}$ is the stress reduction factor.

The stress reduction coefficient $r_{d}$ is expressed in terms of the depth by the following equations (Liao and Whitman 1986) [7]:

$$
\begin{array}{llc}
r_{d}=1.0-0.00765 z & \text { for } & z \leq 9.15 m \\
r_{d}=1.174-0.0267 z & \text { for } & 9.15<z \leq 23 m
\end{array}
$$

\subsubsection{Evaluation of CSR}

For a magnitude $\mathrm{M}$, the cyclic resistance ratio is calculated for a magnitude of 7.5 and corrected by applying a correction factor $\mathrm{CM}$ [8], given in the table below.

$$
C R R=C M . C R R_{7.5}
$$

With:

CM: Correction factor, determined according to Annex B of EN 1998-5 standard [8], based on the magnitude of surface waves $\mathrm{M}$ :

\begin{tabular}{|c|c|}
\hline Ms & CM \\
\hline 5.50 & 2,86 \\
6.00 & 2,20 \\
6.50 & 1,69 \\
7.00 & 1,30 \\
8.00 & 0,67 \\
\hline
\end{tabular}

In this study, the evaluation of CRR is based on the data from SPT test, which is among the most common insitu tests in Morocco.

The $\mathrm{CRR}_{7.5}$ is expressed by the following equation [2]:

$$
C R R_{7.5}=\frac{1}{34-(N 1)_{60}}+\frac{(N 1)_{60}}{135}+\frac{50}{\left[10(N 1)_{60}+45\right]^{2}}-\frac{1}{200}
$$

The following equations were developed by I.M. Idriss with the assistance of R.B. Seed for correction of $\left(\mathrm{N}_{1}\right)_{60}$ to an equivalent clean sand value $\left(\mathrm{N}_{1}\right)_{60 \mathrm{cs}}[2]$ :

$$
(N 1)_{60 c s}=\alpha+\beta(N 1)_{60}
$$

Where $\alpha$ and $\beta$ are coefficients determined from the following relationships:

$$
\begin{aligned}
& \alpha=0 \text { for } \mathrm{FC}<5 \% \\
& \alpha=\exp [1.76-(190 / \mathrm{FC} 2)] \text { for } 5<\mathrm{FC}<35 \% \\
& \alpha=5 \text { for } \mathrm{FC}>35 \% \\
& \beta=1 \text { for } \mathrm{FC}<5 \% \\
& \beta=[0.99+(\mathrm{FC} 1.5 / 1000)] \text { for } 5<\mathrm{FC}<35 \% \\
& \beta=1.2 \text { for } \mathrm{FC}>35 \%
\end{aligned}
$$

According to Black's formula:

$$
\left(\mathrm{N}_{1}\right)_{60}=\mathrm{N}_{\mathrm{m}} \cdot \mathrm{C}_{\mathrm{N}} \cdot \mathrm{C}_{\mathrm{E}} \cdot \mathrm{C}_{\mathrm{B}} \cdot \mathrm{C}_{\mathrm{R}} \cdot \mathrm{C}_{\mathrm{S}}
$$

Where:

$\mathrm{N}_{\mathrm{m}}$ : Measured standard penetration resistance.

$\mathrm{C}_{\mathrm{N}}$ : factor to normalize $\mathrm{Nm}$ to a common reference effective overburden. 
According to Liao and Whitman 1986:

$$
C N=\min \left(\left(P_{a} / \sigma^{\prime} v 0\right)^{0.5} ; 1.7\right)
$$

$\mathrm{C}_{\mathrm{E}}$ : correction for hammer energy ratio (ER).

$$
C E=E R / 60
$$

$E R=100 \times$ specific energy ratio of equipment $(\%)$

$\mathrm{C}_{\mathrm{B}}$ : correction factor for borehole diameter.

$$
\begin{array}{rll}
65<\mathrm{D}<115 \mathrm{~mm} & \rightarrow & \mathrm{CB}=1 \\
115<\mathrm{D}<200 \mathrm{~mm} & \rightarrow & \mathrm{CB}=1.05 \\
\mathrm{D}>200 \mathrm{~mm} & \rightarrow & \mathrm{CB}=1.15
\end{array}
$$

$\mathrm{C}_{\mathrm{R}}$ : correction factor for rod length.

$$
\begin{array}{rll}
\mathrm{L}>3 \mathrm{~m} & \rightarrow & \mathrm{CR}=0.75 \\
3<\mathrm{L}<4 \mathrm{~m} & \rightarrow & \mathrm{CR}=0.8 \\
4<\mathrm{L}<6 \mathrm{~m} & \rightarrow & \mathrm{CR}=0.85 \\
6<\mathrm{L}<10 \mathrm{~m} & \rightarrow & \mathrm{CR}=0.95 \\
\mathrm{~L}>10 \mathrm{~m} & \rightarrow & \mathrm{CR}=1
\end{array}
$$

$\mathrm{C}_{\mathrm{S}}$ : correction for samplers with or without liners.

- Standard sampler $\rightarrow \mathrm{CS}=1$

- $\quad$ Sampler without liners $\rightarrow \mathrm{CS}=1.1$ to 1.3

\subsection{Soil reinforcement}

There are several techniques of soil reinforcement, the choice depends essentially on the granulometry of the soil to be treated [9], these techniques can be classified as follows:

\subsubsection{Improvement of fine soil}

These soils are characterized by:

$\checkmark \quad$ The large deformations they undergo as a result of the loads applied.

$\checkmark \quad$ The deformations are not instantaneous and can last for months or even years.

$\checkmark \quad$ Their bearing capacity is often low.

This may involve excessive settlement, differential settlements, and long-term deformations, resulting in instability or even rupture of the structures.

Techniques for reinforcement of fine soils include:

* Pre-loading: It is a technique, which aims to Consolidate the compressible layers, and to obtain the settlement in order to stabilize the surface of soil before placement of the structure.

* Acceleration of consolidation: In general, the rate of consolidation of fine soil is too low, this is due to the long road that the water has to travel to get out of the soil, which implies a settlement that spreads for a long time. In order to reduce these "unacceptable" durations, a drainage system (vertical and horizontal drains) is put in place to reduce the distance travelled by water.

* Reinforcement by stone columns: They are columns made of granular material, placed in the soil either by backflow (dry process) or by replacing a part of the soil (wet process) and compacted by successive passes.

\subsubsection{Improvement of cohesionless soils}

Unlike fine soil, the permeability of cohesionless soil prevents an increase in pore pressure (except in the case of liquefaction). The problems that this type of soil may encounter are the magnitude of the settlement and the resistance to liquefaction.

Among the methods of reinforcement cohesionless used are:

Pre-loading: the principle is the same as for fine soil, except in this case, the consolidation time is smaller.

$\checkmark$ Vibrocompaction: It includes applying vibration to the soil, using a vibrating needle, which leads to a subsidence of the soil around the needle, reflecting a densification of the soil.

Static compaction: it involves the introduction of mortar in force into the soil, this technique makes it possible to densify the soil and to increase its bearing capacity.

$\checkmark$ Dynamic compaction : It involves repeatedly dropping heavy steel drumsticks (10 to 20 tons) on the soil surface and from a height of 15 to $20 \mathrm{~m}$.

\section{Case study}

Our case study located in Kenitra city, known by sandy deposits varying from more or less clayey sand, to gresified sand with the presence of a very loose layer of sand, at varying depths.

\subsection{Regional data}

\subsubsection{Geological context}

The city of Kenitra forms part of the Gharb basin [10], elongated WSW-ENE and separated from the Bou-Areg plain by the plio-villafranchian trays around Selouane, which rest on the volcanic formations of Bni-Bou -Ifrour and Laglab. At the $\mathrm{W}$, a large pass allows to communicate with the basin of Oued Kerte at the S of Jbel Tistoutine and Jbel Bni-Bou-Ifrour, which close the plain. 


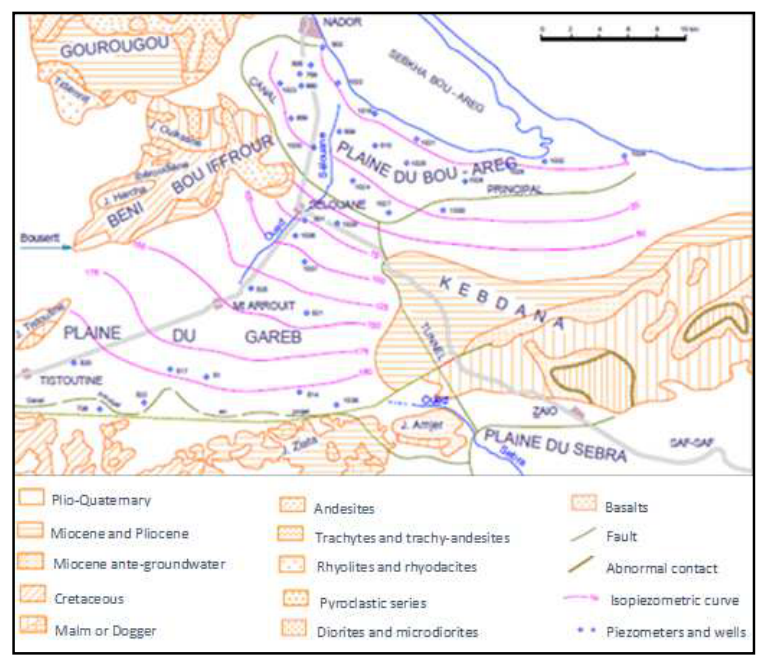

Fig. 1. Geological and piezometric map of the Gharb plain [10]

The Upper Marine Miocene is represented by greyblue marls passing at Pliocene without changing any facies. The relations between Miocene and Pliocene are not very clear, the lagoon-continental deposits from the regression between these two stages can be confused with similar Pliocene deposits.

The Villafranchien lacustrine episode formed white to yellowish limestones passing as well in the horizontal as vertical direction to sublithographic limestones, tuffeous and chalky limestones or nodular marlcalcareous. In the SE and NE parts of Gareb, these limestone facies pass laterally to poorly consolidated conglomerates with clay cement or to well consolidated conglomerates whose elements are often of volcanic origin. Sometimes, these lacustrine formations present lenticular intercalations of pebble and gravel silts. (A.M. Derekoy 1965).

Above this Villafranchien, there is a mid Quatenary represented by fine and red formations attributed to the Amirien and terminated by tennsiftien crusting. The Amirian is formed of red to pink clay silts, more or less calcareous. The Tennsifien is presented as a white tuff, very calcareaous surmounted by a laminated and nodular crust of a few centimeters thick.

Finally the recent Quaternary is present, almost everywhere, in the form of a thin layer of red to brown silts.

\subsubsection{Hydrogeological context}

According to A.M. Derekoy [10], the impermeable base of groundwater is constituted by two distinct units depending on the location. These are either colourful marls, sometimes encompassing pebbles, completely azo, which can be reported to the Pontico-Pliocene or blue-grey marine marls of the base of Pliocene or Upper Miocene.
However, at the SW of the plain, the impermeable level is located in the Quaternary: the drilling made has crossed only pebble silts before finding the detritic limestone of the lower Miocene, at $219 \mathrm{~m}$. The impermeable horizon was actually encountered above the mio-pliocene formations in some drill holes.

The aquifer is dominated by lacustrine formations of Villafranchien and silts with pebbles and gravel in the SW of the plain. It has a lenticular structure, and the impermeable horizon can sometimes be located in the lake levels of Villafranchien.

The map of the iso-piezometric curves (fig 1) shows that the direction of groundwater flow is oriented from the SW and S towards the NE, where the groundwater supplies part of that of the Bou-Areg plain.

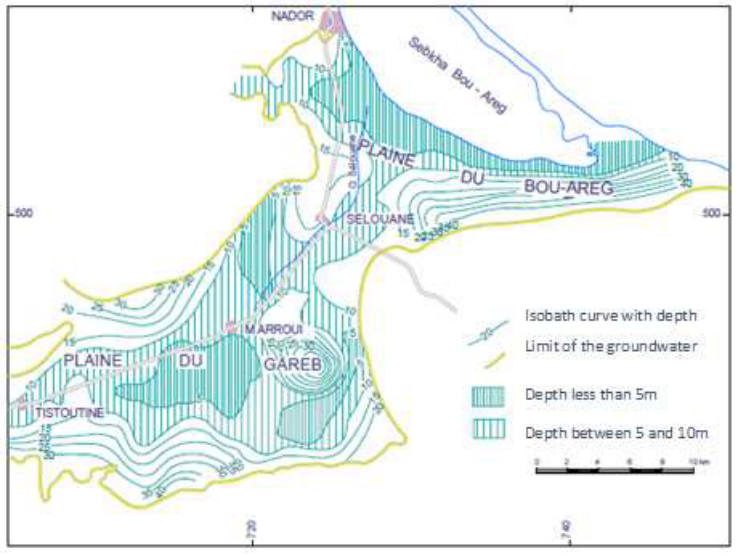

Fig. 2. Map of the isobath curves of the groundwater of the Gharb plain [10]

\subsubsection{Geological context}

It is a semi-arid and meso-thermal climate, with a large rainfall deficit in summer and very little or no surplus in winter [10]. Average annual rainfall is around $600 \mathrm{~mm}$ in the coastal area, but falls to $450 \mathrm{~mm}$ in the SE of plain; however, it should be noted that there are significant interannuel differences since the extremes at Kenitra are between 330 and $841 \mathrm{~mm}$.

The oceanic influence on temperatures is clearly marked by the parallelism at the side of isothermal lines of maps. The point was made that the cold anomaly of winter in the Rharb (absolute minimum: minus $6^{\circ} \mathrm{C}$ ) and a summer temperature consistency that is only disturbed by a few heat strokes when the warm wind blows or chergui of Saharan origin.

The potential evaporation is significant, varies between $865.7 \mathrm{~mm}$ and $912 \mathrm{~mm} /$ year. It follows the evolution of the temperature: It is minimal for the most watered months which favors infiltration. 


\subsection{Results and discussions}

This study is based on data from:

- Core samples coupled with pressuremeter tests,

- $\quad$ SPT tests.

- Granulometric analysis.

- Permeability test.

\subsubsection{Estimation of bearing capacity and settlement generated}

According to the core samples of $15 \mathrm{~m}$ depth, coupled with pressuremeter tests (Tab 1), we evaluated soil's bearing capacity and settlement generated, for a footing of $(2 * 2)$ $\mathrm{m} 2$, anchored in sandy formations, at $1 \mathrm{~m}$ from the surface.

\begin{tabular}{|c|c|c|c|}
\hline $\begin{array}{c}\text { Depth } \\
\text { (m) }\end{array}$ & Lithology & $\begin{array}{c}\text { Limit } \\
\text { presure } \\
\text { PL (Mpa) } \\
\end{array}$ & $\begin{array}{c}\text { Pressuremeter } \\
\text { module } \\
\text { EM (Mpa) } \\
\end{array}$ \\
\hline 1.0 & \multirow{4}{*}{$\begin{array}{l}\text { Fine sand more } \\
\text { or less clay }\end{array}$} & 0.15 & 1.30 \\
\hline 2.5 & & 0.44 & 7.70 \\
\hline 4.0 & & 0.38 & 4.70 \\
\hline 5.5 & & 0.33 & 2.90 \\
\hline 8.5 & $\begin{array}{c}\text { Sand with gritty } \\
\text { passages }\end{array}$ & 2.37 & 44.70 \\
\hline 10.0 & \multirow{4}{*}{ Gritty sand } & 5.12 & 90.60 \\
\hline 11.5 & & 5.02 & 79.50 \\
\hline 13.0 & & 3.42 & 70.30 \\
\hline 14.5 & & 3.44 & 71.00 \\
\hline
\end{tabular}

Tab.1. Results of the first core sample coupled with pressuremeter tests.

The calculation of soil's bearing capacity is summarized in the following table:

\begin{tabular}{|c|c|c|c|}
\hline Ple* $^{*}$ Mpa) & Kp & F & бa (bar) \\
\hline 0.29 & 1.00 & 3.00 & $\mathbf{0 . 9 7}$ \\
\hline
\end{tabular}

The bearing capacity is 0.97 bar, which is low for heavy overloads.

Following a bearing capacity of 0.97 bar, the calculation of soil's settlement are summarized in the table below:

\begin{tabular}{|c|c|c|c|c|c|c|c|c|}
\hline Footing & $\alpha$ & $\lambda_{\mathrm{c}}$ & $\lambda_{\mathrm{d}}$ & $\begin{array}{c}\mathrm{E}_{\mathrm{c}} \\
(\mathrm{Mpa})\end{array}$ & $\begin{array}{c}\mathrm{E}_{\mathrm{d}} \\
(\mathrm{Mpa})\end{array}$ & $\begin{array}{c}\mathrm{S}_{\mathrm{c}} \\
(\mathrm{mm})\end{array}$ & $\begin{array}{c}\mathrm{S}_{\mathrm{d}} \\
(\mathrm{mm})\end{array}$ & $\begin{array}{c}\mathrm{S} \\
(\mathrm{mm})\end{array}$ \\
\hline$(2 * 2) \mathrm{m} 2$ & 0,33 & 1,10 & 1,12 & 1,30 & 3,30 & 6,02 & 6,05 & 12,07 \\
\hline
\end{tabular}

For a bearing capacity of 0.97 bar, the settlement generated is $1.21 \mathrm{~cm}$.

\subsubsection{Assessment of liquefaction risk}

According to the analysis of the SPT test data for the five soundings and granulometric analysis, we have been able to evaluate the factor of safety and the liquefaction risk of each sounding.

\footnotetext{
*hajar.boukhorb@gmail.com
}

\begin{tabular}{|c|c|c|c|c|c|c|c|}
\hline & Depth & Nspt & $\begin{array}{l}\text { FC } \\
(\%)\end{array}$ & CSR & $\begin{array}{c}\text { CRR } \\
(M=7,5)\end{array}$ & $\begin{array}{l}\text { CRR } \\
(M=6)\end{array}$ & Fs \\
\hline \multirow{5}{*}{$\begin{array}{c}\text { SPT } \\
1\end{array}$} & 1,5 & 17 & 41 & 0,180 & 1,034 & 2,275 & 12,645 \\
\hline & 3,5 & 8 & 41 & 0,177 & 0,192 & 0,422 & 2,38 \\
\hline & 5,5 & 6 & 28 & 0,174 & 0,131 & 0,287 & 1,647 \\
\hline & 7,5 & 4 & 21 & 0,172 & 0,094 & 0,207 & 1,208 \\
\hline & 8,5 & 3 & 14 & 0,17 & 0,071 & 0,157 & 0,924 \\
\hline \multirow{5}{*}{$\begin{array}{c}\text { SPT } \\
2\end{array}$} & 1,5 & 11 & 37 & 0,18 & 0,256 & 0,564 & 3,133 \\
\hline & 3,5 & 17 & 32 & 0,177 & 0,675 & 1,484 & 8,378 \\
\hline & 5,5 & 19 & 37 & 0,174 & 0,442 & 0,972 & 5,573 \\
\hline & 10,5 & 8 & 16 & 0,163 & 0,107 & 0,236 & 1,453 \\
\hline & 11,5 & 9 & 16 & 0,158 & 0,112 & 0,246 & 1,558 \\
\hline \multirow{5}{*}{$\begin{array}{c}\text { SPT } \\
\mathbf{3}\end{array}$} & 2,5 & 10 & 45 & 0,179 & 0,233 & 0,512 & 2,866 \\
\hline & 4,5 & 11 & 35 & 0,176 & 0,225 & 0,495 & 2,815 \\
\hline & 6,5 & 3 & 20 & 0,173 & 0,086 & 0,19 & 1,097 \\
\hline & 8,5 & 8 & 11 & 0,17 & 0,099 & 0,217 & 1,277 \\
\hline & 10,5 & 5 & 10 & 0,163 & 0,071 & 0,156 & 0,96 \\
\hline \multirow{5}{*}{$\begin{array}{c}\text { SPT } \\
4\end{array}$} & 3,5 & 11 & 31 & 0,177 & 0,243 & 0,534 & 3,017 \\
\hline & 5,5 & 2 & 23 & 0,174 & 0,083 & 0,183 & 1,049 \\
\hline & 7,5 & 6 & 15 & 0,172 & 0,099 & 0,217 & 1,263 \\
\hline & 9,5 & 4 & 13 & 0,168 & 0,074 & 0,163 & 0,975 \\
\hline & 11,5 & 1 & 15 & 0,158 & 0,06 & 0,132 & 0,838 \\
\hline \multirow{5}{*}{$\begin{array}{c}\text { SPT } \\
5\end{array}$} & 2,5 & 14 & 22 & 0,179 & 0,287 & 0,631 & 3,535 \\
\hline & 4,5 & 12 & 16 & 0,176 & 0,19 & 0,418 & 2,38 \\
\hline & 6,5 & 6 & 21 & 0,173 & 0,115 & 0,254 & 1,466 \\
\hline & 9,5 & 9 & 9 & 0,168 & 0,097 & 0,212 & 1,267 \\
\hline & 10,5 & 2 & 13 & 0,163 & 0,062 & 0,135 & 0,833 \\
\hline
\end{tabular}

It is found that the most affected depths are between 5.5 and $11.5 \mathrm{~m}$, with a high liquefaction risk at the sandy soils, hence the need to ameliorate their characteristics.

\subsubsection{Soil treatment}

a. Treatment choice

According to the paragraph 3.2.2, there is a risk of soil liquefaction at depths between 5.5 and $11.5 \mathrm{~m}$. The granulometric analysis shows that the clay contents are greater than $14 \%$, therfore, the vibro-compaction alone cannot constitute a treatment. Moreover, we opt for a 
treatment by stone columns, since the column intervenes at three levels [11]:

- Reduction of shear stress applied on soil ;

- Evacuation of interstitial pressures ;

- Increasing soil compactness between columns.

b. Dimensioning of stone columns

The dimensioning of stone columns is founded on the document: Recommendations for the design, calculation, construction and quality control of stone columns under buildings and sensitive structures (CFMS) [12], on the basis of the data from pressuremeter tests.

The dimensioning were carried out for footing of $(2 * 2) \mathrm{m}^{2}$, whose surface $\mathrm{Ss}=4 \mathrm{~m}^{2}$, supported on 4 columns of $0.8 \mathrm{~m}$ diameter with area $\mathrm{S}_{\mathrm{col}}=0.5 \mathrm{~m}^{2}$, bearing surface load $\mathrm{q}_{\mathrm{ELS}}=1.5$ bars.

* First, we check the condition:

$$
\left\{n \cdot S_{c o l} \cdot q_{a}+\left[\left(S_{s}-n, S_{c o l}\right) \cdot q_{u}^{\prime} / 3\right]\right\}>q_{E L S .} S_{s}
$$

Where:

$\mathrm{n}$ : Number of columns.

$\mathrm{q}_{\mathrm{a}}$ : Maximum allowable stress within the column.

$\mathrm{q}_{\mathrm{u}}$ : Soil failure stress before improvement under a centered load.

According to the document of Recommendations for the design, calculation, construction and quality control of stone columns under buildings and sensitive structures (CFMS) [13], The maximum allowable stress within the column is equal to:

$$
q_{a}=\min \left(0.8 ; 2 P_{l}^{*}\right)
$$

Where $\mathrm{P}_{1} *$ is the equivalent limit pressure, deduced from pressuremeter tests, $\mathrm{P}_{1} *=0.29 \mathrm{Mpa}$.

$$
\mathrm{q}_{\mathrm{a}}=0.58 \mathrm{MPa}
$$

According to Fascicule 62 [1], the soil failure stress is equal to:

$$
q_{u}{ }^{\prime}=k_{P} \cdot P_{l}^{*}
$$

With $\mathrm{k}_{\mathrm{p}}$ is lift coefficient of sandy formations $\left(\mathrm{k}_{\mathrm{p}}=1\right)$.

$$
\mathrm{q}_{\mathrm{u}}{ }^{\prime}=0.29 \mathrm{MPa}
$$

$\left\{\mathrm{n} \cdot \mathrm{S}_{\mathrm{col}} \cdot \mathrm{q}_{\mathrm{a}}+\left[\left(\mathrm{S}_{\mathrm{s}}-\mathrm{n}, \mathrm{S}_{\mathrm{col}}\right) \cdot \mathrm{q}_{\mathrm{u}}^{\prime} / 3\right]\right\}=3.40$ bars $>\mathrm{q}_{\mathrm{ELS}}$

$\rightarrow$ Condition checked.

* Then, we calculate the settlement $\mathrm{w}_{\mathrm{s}}$ without treatment for $\mathrm{q}_{\mathrm{ELS}}=1.5 \mathrm{bars}$, on the basis of the Ménard pressuremeter method, $\mathrm{w}_{\mathrm{s}}=1.87 \mathrm{~cm}$.

Thus the following can be determined:

$$
K_{s}=q_{E L S} / w_{s}
$$

Where $K_{s}$ is the soil stiffness.

$$
\mathrm{K}_{\mathrm{s}}=8.02 \mathrm{MPa} / \mathrm{m}
$$

* The settlement equation for a column $\mathrm{w}_{\mathrm{col}}$ with stress at the head $\mathrm{q}_{\mathrm{col}}$ is :

$$
w_{c o l}=\beta^{\prime} \cdot q_{c o l} . H / E_{c o l}
$$

Where $\mathrm{H}$ is the level at which the settlement is calculated; $\beta^{\prime}$ is a ratio that shows that there is a distribution of stress from the column to the soil; $\mathrm{E}_{\mathrm{col}}$ is the young's modulus of column $\left(\mathrm{E}_{\mathrm{col}}=60 \mathrm{MPa}\right)$.

In practice, $\mathrm{H}=\min (2.5 \mathrm{~B} ; \mathrm{Lc})=\min (5 ; 12)=5 \mathrm{~m}$, is used since over $85 \%$ of soil settlement occurs between 0 and $2.5 \mathrm{~B}$, and we retain: $\beta$ ' $=1$ (no distribution).

Thus, we determine stresses transmitted to the soil and columns, qs and qcol respectively, on the basis of the following two equations:

- Equality of soil settlement and column settlement:

$$
\frac{q_{S}}{K_{S}}=\frac{q_{c o l}}{K_{c o l}}
$$

With:

$$
K_{c o l}=E_{c o l} /\left(\beta^{\prime}, H\right)
$$

- Stress distribution between soil and columns:

$$
\left\{n \cdot S_{c o l} \cdot q_{c o l}+\left[\left(S_{s}-n \cdot S_{c o l}\right) \cdot q_{s}\right]\right\}=q_{E L S} \cdot S_{S}
$$

We obtain: $\quad q_{\text {col }}=\mathbf{2 . 0 7}$ bars and $q_{\mathrm{s}}=\mathbf{0 . 9 3}$ bars .

* The column stiffness can be deduced and expressed as:

$$
\begin{aligned}
& \mathrm{K}_{\mathrm{col}}=\mathrm{E}_{\mathrm{col}} /\left(\beta^{\prime}, \mathrm{H}\right) \\
& \mathbf{K}_{\mathrm{col}}=\mathbf{1 7 . 9} \mathbf{M P a} / \mathbf{m}
\end{aligned}
$$

* In this step, the stiffness of the entire " footing+ column" structure at the height in question:

$$
K=\left\{\left[k_{s} \cdot\left(S_{s}-n \cdot S_{c o} l\right)\right]+\left(n \cdot k_{c o l} S_{c o l}\right)\right\} /(B L)
$$

$$
\mathrm{K}=12.96 \mathrm{MPa} / \mathrm{m}
$$

* The following can then be deduced:

- The settlement after treatment at height $\mathrm{H}$ :

$$
\begin{aligned}
w_{s H} & =q_{E L S} / K \\
\mathrm{w}_{\mathrm{sH}} & =1.16 \mathrm{~cm}
\end{aligned}
$$

- The final settlement after treatment:

$$
\begin{gathered}
w_{s f}=w_{s H} / 0.85 \\
\mathrm{w}_{\mathrm{sH}}=1.36 \mathrm{~cm}
\end{gathered}
$$

* We finally check that the values are still within the range of pseudo-elastic validity:

$$
\begin{aligned}
& \mathrm{q}_{\mathrm{s}}=0.93 \text { bars }<\mathrm{k}_{\mathrm{p}} . \mathrm{P}_{\mathrm{le}} / 2+\mathrm{q}^{\prime} 0=1.45 \text { bars } \\
& \mathrm{q}_{\mathrm{co}} \mathrm{l}=2.07 \text { bars }<\mathrm{q}_{\mathrm{a}}=5.80 \mathrm{bars} \\
& \mathrm{w}_{\mathrm{sf}}=1.36 \mathrm{~cm} \rightarrow \text { Admissible. }
\end{aligned}
$$

*hajar.boukhorb@gmail.com 
The installation of 4 stone columns of $0.8 \mathrm{~m}$ diameter and $12 \mathrm{~m}$ length under an isolated footing of $(2 * 2) \mathrm{m}^{2}$, has improved the bearing capacity from 0.97 to 1.50 bars. However, the risk of soil liquefaction, after treatment, will be verified in the next chapter.

c. Evaluation of liquefaction mitigation by stone columns

To reduce the potential risk of liquefaction, Seed and Booker (1977) proposed a method based on dissipation of excess pore pressure [13]. The aim is to find a ratio $\mathrm{ru}=\mathrm{U}$ / $\sigma^{\prime} v 0 \leqslant 0.6$ for having a safety factor greater than 1.33 , according to the RPS 2000 version 2011 [6]. This ratio is deduced from FIG. 4 and it is a function of Neq / Nl and an adimensional parameter Tad, with:

a: Radius of stone column, $(\mathrm{a}=0.4 \mathrm{~m})$.

b: column's radius of Influence, for square grid, $\mathrm{b}=1.13 * \mathrm{I} / 2$, where $\mathrm{I}$ is the interspace spacing, $(\mathrm{I}=1.2 \mathrm{~m}$ and $\mathrm{b}=0.678 \mathrm{~m})$.

$\mathrm{N}_{\text {eq }}$ : Number of seism equivalent cycles, defined in Tab. $3\left(\mathrm{~N}_{\mathrm{eq}}=8\right.$ for a mean seismicity zone).

$\mathrm{N}_{1}$ :Number of cycles leading to liquefaction, deduced from nomogram of Fig. 3 [8], $\left(\mathrm{N}_{1} \approx 8\right)$.

$\mathrm{T}_{\mathrm{ad}}$ : dimensionless parameter defined by the following formula:

$$
T_{a d}=\frac{K_{S} \cdot t_{d}}{m_{V} \cdot a^{2} \cdot \gamma_{w}}
$$

Where:

$\mathrm{K}_{\mathrm{s}}$ : soil's horizontal permeability $\left(\mathrm{K}_{\mathrm{s}}=3.4 * 10-5 \mathrm{~m} / \mathrm{s}\right)$

$t_{d}$ : Duration of seism $\left(t_{d}=14 \mathrm{~s}\right.$ for a mean seismicity zone).

$\gamma_{\mathrm{w}}$ : Density of water.

$\mathrm{m}_{\mathrm{v}}$ : Soil compressibility $\mathrm{m}_{\mathrm{v}}=1 / \mathrm{E}_{\mathrm{oed}} \mathrm{By}$

By correlation with pressuremeter test results (Tab.2):

$$
E_{\text {oed }}=\alpha / E_{M}
$$

with:

$\mathrm{E}_{\text {oed }}$ is the oedometer modulus.

$\mathrm{E}_{\mathrm{M}}$ is the pressuremeter modulus.

\begin{tabular}{|c|c|c|c|}
\hline $\begin{array}{c}\text { Depth } \\
\text { (m) }\end{array}$ & Lithology & PL (Mpa) & EM (Mpa) \\
\hline 1.0 & \multirow{6}{*}{$\begin{array}{c}\text { Fine sand more } \\
\text { or less clay }\end{array}$} & 2,29 & 37,5 \\
\hline 2.5 & & 1,82 & 25,5 \\
\hline 4.0 & & 1,12 & 11,3 \\
\hline 5.5 & & 0,14 & 1,3 \\
\hline 7 & & 0,21 & 1,5 \\
\hline 8,5 & & 0,28 & 6,3 \\
\hline
\end{tabular}

$\alpha$ is the soil rheological coefficient.

\begin{tabular}{|c|c|c|c|}
\hline 10 & & 0,48 & 8,2 \\
\hline 11,5 & & 0,42 & 4,3 \\
\hline 13 & Sand with & 1,83 & 22,7 \\
\hline 14,5 & gritty passages & 2,72 & 36,7 \\
\hline 16 & \multirow{5}{*}{ Gritty sand } & 3,74 & 70,1 \\
\hline 17,5 & & 4,16 & 115,4 \\
\hline 19 & & 5,1 & 118,3 \\
\hline 20,5 & & 5,12 & 153,6 \\
\hline 22 & & 5,15 & 108,1 \\
\hline
\end{tabular}

hajar.boukhorb@gmail.com
Tab.2. Results of the second core sample coupled with pressuremeter tests.

\begin{tabular}{|c|c|c|c|}
\hline $\begin{array}{c}\text { Seismicity } \\
\text { zone }\end{array}$ & $\begin{array}{c}\text { Conventional } \\
\text { magnitude }\end{array}$ & $\begin{array}{c}\text { Number of } \\
\text { equivalent } \\
\text { earthquake } \\
\text { cycles Neq }\end{array}$ & $\begin{array}{c}\text { Duration } \\
\text { of the } \\
\text { earthquake } \\
\text { td (s) }\end{array}$ \\
\hline $\begin{array}{c}3 \\
\text { (moderate) }\end{array}$ & 5.5 & 4 & 8 \\
\hline 4 \\
(average)
\end{tabular}

Tab. 3. Number of equivalent cycles and duration of the earthquake according to the seismicity zone [13]

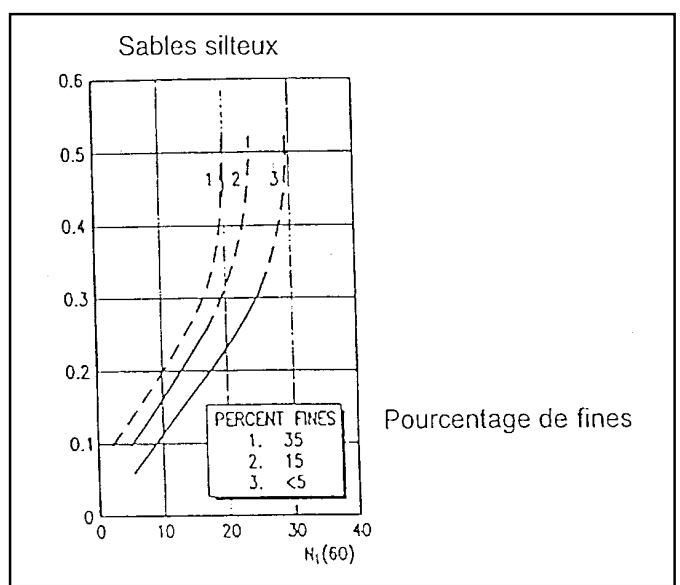

Fig. 3. Number of cycles leading the soil to liquefaction according to the percentage of fine [8] 


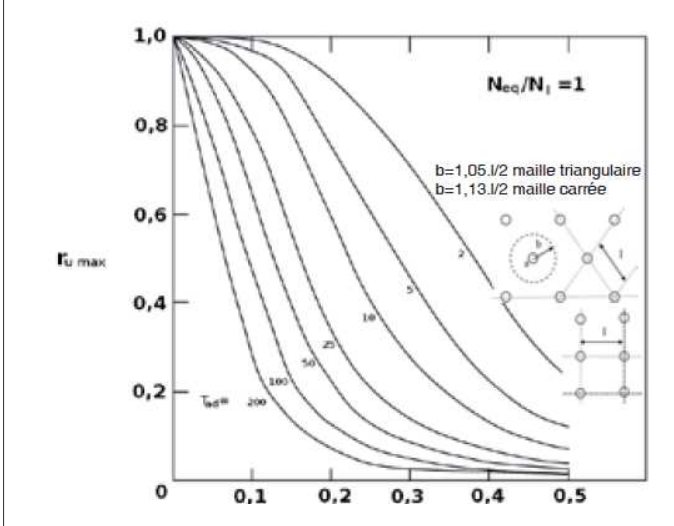

Fig. 4. Determination of the ratio a / b, Booker et al. 1976 [13]

This method does not take into account the dilating character of gravel, which reduce more the interstitial overpressures (from 11 to $17 \%$ according to Madhav et al., 2000).

\begin{tabular}{|c|c|c|c|c|c|c|}
\hline & $\begin{array}{c}\text { Depth } \\
\text { (m) }\end{array}$ & $\begin{array}{c}\text { EM } \\
\text { (Mpa) }\end{array}$ & $\alpha$ & $\begin{array}{c}\mathbf{m v} \\
\left(\mathbf{M p a}^{-1}\right)\end{array}$ & Tad & ru max \\
\hline \multirow{2}{*}{$\begin{array}{c}\text { SPT } \\
\mathbf{1}\end{array}$} & 7,5 & 1,5 & 0,33 & 0,22 & 1,35 & $<0,6$ \\
\hline & 8,5 & 6,3 & 0,5 & 0,08 & 3,75 & $<0,6$ \\
\hline \multirow{3}{*}{$\begin{array}{c}\text { SPT } \\
\mathbf{3}\end{array}$} & 6,5 & 1,5 & 0,33 & 0,22 & 1,35 & $<0,6$ \\
\hline & 8,5 & 6,3 & 0,5 & 0,08 & 3,75 & $<0,6$ \\
\hline & 10,5 & 8,2 & 0,5 & 0,061 & 4,88 & $<0,6$ \\
\hline \multirow{4}{*}{$\begin{array}{c}\text { SPT } \\
4\end{array}$} & 5,5 & 1,3 & 0,33 & 0,25 & 1,17 & $<0,6$ \\
\hline & 7,5 & 1,5 & 0,33 & 0,22 & 1,35 & $<0,6$ \\
\hline & 9,5 & 8,2 & 0,5 & 0,061 & 4,88 & $<0,6$ \\
\hline & 11,5 & 4,3 & 0,33 & 0,077 & 3,88 & $<0,6$ \\
\hline \multirow{2}{*}{$\begin{array}{c}\text { SPT } \\
5\end{array}$} & 9,5 & 8,2 & 0,5 & 0,061 & 4,88 & $<0,6$ \\
\hline & 10,5 & 4,3 & 0,33 & 0,077 & 3,88 & $<0,6$ \\
\hline
\end{tabular}

According to the table above, $\mathrm{r}_{\mathrm{u} \text { max }}$ is well below 0.6 , therefore the liquefaction risk of sands is discarded at depths initially liquefiable, hence the effectiveness of treatment.

\section{Conclusion}

The Kenitra city is clearly invaded by sandy deposits. It's with this directive that the present study has allowed to focus on the problems of these soils, in particular the low bearing capacity and the liquefaction risk.

Based on the data from in-situ geotechnical survey and in laboratory, we were able to confirm the low bearing capacity of these sandy formations and the liquefaction at depths between 5.5 and $11.5 \mathrm{~m}$.

hajar.boukhorb@gmail.com
In view of the high clay contents, which are greater than $14 \%$, the vibro-compaction alone cannot constitute a treatment. Thus, we opt for a treatment by stone columns, by installing four columns of $0.8 \mathrm{~m}$ diameter under a square insulated footing of $(2 * 2) \mathrm{m}^{2}$.

This treatment was able to improve, on the one hand, the bearing capacity from $0.97 \mathrm{MPa}$ to $1.50 \mathrm{MPa}$, and eliminate, on the other hand, the risk of liquefaction on the initially liquefiable horizons.

\section{References}

1. Fascicule $\mathrm{n}^{\circ}$ 62, Titre V-Conception et calcul des fondations des ouvrages de Génie Civil, Editions des journaux officiels (1993).

2. H.B. Seed, I.M. Idriss, J Soil Mech Found Div, Simplified procedure for evaluating soil liquefaction potential, 97(SM9), 1249-1273 (1971).

3. I.M. Idriss, R.W. Boulanger, Soil liquefaction during earthquakes, $2^{\text {nd }}$ edition, Earthquake Engineering Research Institute (2008).

4. I.M.Idriss, R.W, Boulanger, SPT-based liquefaction triggering procedure, Centre for Geotechnical Modeling, Department of Civil and Environmental Engineering, Universitu of California, Davis, California (2010).

5. T. Youd, I.M. Idriss, R.D. Andrus, I. Arango, G. Castro and J.T. Christian, Journal of Geotechnical and Geoenvironmental Engineering, Liquefaction resistance of soils : Summary report from the 1996 Nceer and 1998 NCEER/NSF Workshops on evaluation of liquefaction resistance of soils, 817-833, (2001).

6. Le Règlement de construction parasismique RPS 2000, version 2011, Direction de la qualité et des affaires techniques, Ministère de l'Habitat et de la Politique de la ville au Maroc (2011).

7. S.S.C. Liao and R.V. Whitman: A catalog of liquefaction and Non-liquefaction occurrences During Earthquakes, Department of civil Engineering, Massachusetts institute of technology, Cambridge, MA, 117 pp (1986).

8. Normalisation française XP ENV 1998 - 5, Eurocode8: Conception de dimensionnement des structures pour leur résistance aux séismes et Document d'Application Nationale, Partie 5 : Fondations, ouvrages de soutènement et aspects géotechnique (Décembre 2000). 9. Laurent Briançon, Philippe Liausu, Claude Plumelle, Bruno Sumon, Amélioration et renforcement des sols Tome 1, Le Moniteur (Avril 2018).

10. Ph. CARLIER, Ressources en Eau du Maroc Tome1 : Domaines du Rif et du Maroc oriental, Editions du service géologique, division des ressources en eau, direction de l'hydraulique, ministère des travaux publics et des communications du Maroc (1975).

11. A. Dhouib, F. Blondeau, Colonnes Ballastées Techniques de mise en oeuvre, domaines d'application, comportement, justifications, axes de recherches et de développement, Presses de l'école nationale des Ponts et Chaussées (2005).

12. P. Aguado, P. Berthelot, L. Carpinteiro, F. Durand, 
M. Glandy, Ph. Liausu, B. Pezot, Ch. Poilpre, S. Lambert, J.P. Volcke, Recommandations sur la conception, le calcul, l'exécution et le contrôle des colonnes ballastées sous bâtiments et sous ouvrages sensibles au tassement, Revue française de Géotechnique, version $n^{\circ} 2$ (2011).

13. Lambert S, Keller Fondations Spéciales, Evaluation de la réduction du risque de liquéfaction par des colonnes ballastées, Proceeding of the 18th International Conference on Soil Mechanics and Geotechnical Engineering, Paris (2013). 